\title{
Keefektifan Teknik Imagine terhadap Kemampuan Menulis Puisi Bebas Siswa Kelas VIII SMP Negeri 2 Palopo
}

\author{
Sehe Madeamin \\ Program Studi Pendidikan Guru Sekolah Dasar \\ Fakultas Keguruan dan Ilmu Pendidikan \\ Universitas Cokroaminoto Palopo \\ madeamin.sehe@yahoo.com

\begin{abstract}
Abstrak
Penelitian ini adalah penelitian kuantitatif dengan menggunakan model eksperimen. Tujuan dalam penelitian ini adalah untuk mendeskripsikan keefektifan teknik imagine terhadap kemampuan menulis puisi bebas siswa kelas VIII SMP Negeri 2 Palopo. Teknik pengambilan sampel diambil secara purposive sampling. Tujuh kelas homogen dirandom untuk menentukan dua kelas perlakuan. Dari dua kelas terpilih, dirandom kembali untuk menentukan satu kelas eksperimen dan kelas kontrol. Perlakuan pada kelas eksperimen adalah menerapkan teknik imagine (khayalan visual) terhadap kemampuan menulis puisi bebas dan kelas kontrol tanpa menerapkan teknik imagine (khayalan visual). Pengumpulan data dilakukan dengan pemberian ujian atau tes. Analisis statistika yang digunakan untuk mengolah data hasil penelitian adalah analisis statistika deskriptif dan inferensial. Kemampuan siswa kelas VIII A SMP Negeri 2 Palopo yang menerapkan teknik imagine (khayalan visual) dan kemampuan kelas kelas VIII D SMP Negeri 2 Palopo yang tanpa menerapkan teknik imagine (khayalan visual). Hasil penelitian menunjukkan bahwa Teknik Imagine efektif digunakan terhadap kemampuan menulis puisi bebas siswa kelas VIII SMP Negeri 2 Palopo. Keefektifan yang dimaksud berada pada kategori sedang dengan skor rata-rata 73,96 dari skor ideal 100 dan standar deviasi 11,70.
\end{abstract}

Kata-kata Kunci : Teknik Imagine (khayalan Visual), Menulis Puisi Bebas

\section{Pendahuluan}

Pentingnya pembelajaran bahasa untuk diajarkan di sekolah-sekolah, terutama pembelajaran bahasa Indonesia. agar siswa lebih diarahkan pada pada kepemilikan kompetensi dan keterampilan untuk mampu berkomunikasi secara lisan maupun tulis.

Kegiatan menulis bertujuan untuk mengungkapkan fakta-fakta, pesan, sikap dan isi pikiran secara jelas dan efektif kepada para pembacanya. Menulis merupakan suatu kegiatan yang produktif dan ekspresif (Tarigan 1982:4). Di pihak lain, (Dalman, 2018:3) mengemukakan bahwa menulis merupakan suatu kegiatan komunikasi berupa penyampaian pesan (informasi) secara tertulis kepada pihak lain dengan menggunakan bahasa tulisan sebagai alat atau medianya.

Selanjutnya, Zainurrahman (2013: 9) mengungkapkan bahwa dalam menulis, ada hal yang tidak dapat diperoleh secara alami dan harus mendapatkan perhatian lebih, karena keterampilan-keterampilan tersebut tidak dapat diperoleh melalui interaksi spontan dan alamiah. Untuk meningkatkan keterampilan menulis harus melalui latihan-latihan. Keterampilan menulis hanya akan dapat dikembangkan melalui proses latihan dan bukan hanya 
sekadar membaca buku. Demikian pula, keterampilan menulis hanya dapat diraih secara sempurna jika praktik atau latihan dilatarbelakangi oleh pemahaman teoretis. Dengan kata lain, dalam proses latihan menulis, teori dan praktik tidak dapat dipisahkan. Menulis memang harus melalui proses belajar dan berlatih. Semakin sering belajar dan berlatih, tentu semakin cepat terampil. Seseorang yang sudah biasa menuliskan sebuah ide, gagasan, pendapat, atau perasaannya, maka dia tidak akan mengalami kesulitan dalam mewujudkan tulisannya.

Teknik imagine merupakan teknik yang mengaktifkan siswa dari khayalan visual peserta didik itu sendiri untuk menciptakan ide-idenya. Karena melalui khayalan itu efektif sebagai suplemen kreatif untuk peserta didik pada belajar kolaboratif. Melalui teknik ini peserta didik akan diberikan stimulas dan bimbingan untuk menciptakan dan membangun ide-ide mereka yang akan mereka ceritakan atau mereka tuangkan dalam sebuah tulisan berupa puisi. https://id.wikihow.com/Menuliskan-Puisi-Bebas.

Dalam rangka mewujudkan pembelajaran menulis puisi bebas yang bermanfaat maka gambaran di atas dapat dijadikan alasan dilakukannya perbaikan proses pembelajaran yang sesuai dengan tujuan pembelajaran dengan menggunakan teknik yang relevan.

\section{Teknik Imagine}

Teknik Imagine (Khayalan Visual) merupakan segalah yang dirasai atau yang dialami secara imajinatif (Tarigan, 2011:31). Imajinasi merupakan unsur yang mengembangkan rasa keindahan dalam diri kita yang menaggapi suatu karya seni. Bagi seniman adalah unsur krasi, unsur penciptan seni. Keindahan merupakan perkara yang subjektif. Dengan demikian, dalam karya sang penyair berusaha sekuat daya agar para penikmat dapat melihat, merasakan, mendegarkan, menyentuh, bahkan bila perlu mengalami sesuatu yang terdapat dalam sajaknya, sebab hanya dengan jalan demikian sajalah dia dapat menyakinkan para penikmat terhadap realitas dari segalah sesuatu yang sedang didendangkannya itu. Semua penyair ingin menyuguhkan pengalaman batin yang pernah dialminya kepada para penikmat karyanya. Salah satu usaha untuk memenuhi keinginan tersebut ialah dengan pemilihan serta penggunaan katakata yang tepat dalam karya mereka. Pilihan serta penggunaan kata-kata yang tepat itu dapat memperkuat serta memperjelas imajinasi pikiran manusia dan energi tersebut dapat pula mendorong imajinasi untuk menjelmakann gamaran yang nyata.

Citraan penglihatan adalah citraan yang timbul oleh penglihatan. Citraan ini memberikan rangsangan kepada indra penglihatan, sehingga hal-hal yang tak terlihat seolah-olah terlihat.

Berdasarkan beberapa pegertian yang dikemukakan di atas, maka dapat dikatakan bahwa Teknik imagine (khayalan visual) adalah segalah yang dirasai atau dialami secara imajinatif oleh penyair dalam karyannya agar bisa memberi 
gambaran yang jelas atau bayagan visual penyair mengambarkan suatu pikiran kepada pembaca.

\section{Kelebihan Teknik Imagine}

a. Akan membuat pembelajaran lebih menarik dan kratif serta menarik minat siswa dengan kegiatan menggunakan khayalan visual.

b. Stimulus yang jelas dari guru mempermudah siswa menggunakan imajinasinya untuk membagun khayalan.

c. Siswa lebih mudah menuliskan hasil ciptaan ide-ide dengan bimbingan guru. Menurut Tarigan (2000:12)

3. Langkah-Langkah Pemelajaran Teknik Imagine

1. Memperkenalkan topik yang akan dicakup.

2. Menjelaskan kepada peserta didik bahwa pelajaran menuntut kreativitas dan penggunaan Khayalan Visual bisa membantu usaha mereka.

3. Menginstruksikan kepada Kelas untuk menutup mata mereka.

4. Meminta peserta didik, dengan mata yang tertutup untuk menutup memvisualisasikan cahaya dan suara seperti kuntum bunga, kamar tidur mereka, lampu lalu lintas yang berubah atau rintik hujan.

5. Ketika anggota kelas rileks, guru menyiapkan satu Khayalan bagi siswa untuk di bangun. Misalnya kereta api yang sedang melaju.

6. Ketika Khayalan dilukiskan, siapkan jarak sunyi sehingga peserta didik dapat membangun Khayalan Visual mereka sendiri.

7. Simpulkan panduan Khayalan dan instruksikan kepada anggota kelas untuk mengigat Khayalannya.

8. Dengan perlahan akhiri latihan.

9. Mintalah peserta didik untuk membentuk kelompok-kelompok kecil dan saling membagi pengalamannya.minta mereka untuk melukiskan khayalan kepada lainnya dengan menggunakan panca indra sebanyak mungkin. Dan minta mereka untuk menuliskan tentang khayalannya. Silberman (2007:183).

\section{Metode Penelitian}

Penelitian ini adalah penelitian eksperimen yang bersifat kuantitatif dengan menggunakan model eksperimen. Desain yang digunakan dalam penelitian ini adalah true eksperimental desain pretest posttest control group desaign. Dalam desain ini, terdapat dua kelas perlakuan. Kedua kelas ini sebobot kecuali pada perlakuan variabel bebas yang hanya dikenakan pada kelas eksperimen.

Table 1. Desain Penelitian

\begin{tabular}{|llll|}
\hline $\mathrm{E}$ & $\mathrm{O}_{1}$ & $\mathrm{x}$ & $\mathrm{O}_{2}$ \\
$\mathrm{~K}$ & $\mathrm{O}_{3}$ & - & $\mathrm{O}_{4}$ \\
\hline
\end{tabular}

Sumber: Sugiyono 2014

Keterangan:

E : Kelas eksperimen

$\mathrm{K} \quad$ : Kelas kontrol 
$\mathrm{O}_{1} \quad$ : Pretest (tes awal kelas eksperimen)

$\mathrm{O}_{3} \quad$ : Pretest (tes awal kelas kontrol)

$\mathrm{X} \quad$ : Treatment/perlakuan (teknik imagine)

- $\quad$ : tidak diberi perlakuan

$\mathrm{O}_{2} \quad$ : Posttest (tes akhir kelas eksperimen)

$\mathrm{O}_{4} \quad$ : Posttest (tes akhir kelas kontrol)

\section{Teknik Pengumpulan Data}

Pengumpulan data pada penelitian ini, dilakukan dengan menggunakan model tes. Model tes adalah suatu model yang dilakukan dengan memberikan latihan yang digunakan untuk mengukur kemampuan siswa. Teknik pengumpulan data diperoleh dari kelas eksperimen dan kelas kontrol, melalui langkah-langkah sebagai berikut:

1. Teknik Tes

a. Memberikan tes awal (pretest) kepada kelas eksperimen dan kelas kontrol tentang menulis puisi bebas.

b. Memberikan perlakukan (treatment) pada kelas eksperimen dengan menggunakan teknik/strategi imagine pada pembelajaran menulis puisi bebas.

c. Memberikan materi tentang menulis puisi bebas pada kelas kontrol tanpa menggunakan teknik/strategi imagine dalam pembelajaran menulis.

d. Memberikan tes akhir (posttest) pada kelas eksperimen dan kelas kontrol.

Selain teknik Tes Penulis juga menggunakan teknik nontes seperti:

a. Observasi adalah proses pengamatan dan pencatatan secara sistematis mengenai gejalah-gejalah yang di teliti.

b. Dokumentasi adalah mengumpulkan data dengan cara mengambil data dari catatan, dokumentasi dan ainistrasi yang sesuai dengan masalah yang diteliti.

c. Wawancara adalah suatu cara mengumpulkan data dengan informasi atau autoritas yang berwewenang dalam suatu masalah.

\section{Teknik Analisis Data}

Analisis data yang digunakan dalam penelitian ini yaitu Statistika Deskriptif dan Statistik Inferensial.

Statistika deskriptif adalah menyajikan informasi dalam bentuk yang tepat, dapat digunakan dan dapat dimengerti. Statistik deskriptif digunakan untuk mendeskripsikan karakteristik responden berupa rata-rata hasil belajar dan standar deviasi, baik responden pada kelas eksperimen maupun responden pada kelas kontrol. Untuk keperluan analisis digunakan rata-rata, standar deviasi, distribusi frekuensi, untuk masing-masing kelompok.

Data yang diperoleh dari hasil test pretest dan posttes dianalisis untuk mengetahui keefektifan teknik imagine terhadap peningkatan hasil belajar siswa. Untuk mengetahui hasil belajar siswa sebelum dan sesudah siswa diberikan perlakuan mengikuti pedoman sebagai berikut: 
Tabel 3. Pedoman Pembelajaran

\begin{tabular}{cc}
\hline Skor & Kategori \\
\hline $0-54$ & Sangat rendah \\
$55-64$ & Rendah \\
$65-79$ & Sedang \\
$80-89$ & Tinggi \\
$90-100$ & Sangat tinggi \\
\hline
\end{tabular}

Sumber: SMP Negeri 2 Palapo (2019)

Dalam penelitian pembelajaran dikatakan optimal apabila persentase minimal mencapai kategori sangat baik.

Tabel 4. Frekuensi Kuantitatif Perolehan Nilai Disesuaikan KKM

\begin{tabular}{llll}
\hline No & Perolehan Nilai & Frekuensi & Persentasi (\%) \\
\hline 1 & Nilai $75 \geq$ ke atas & & \\
2 & Nilai $75<$ ke bawah & & \\
\hline
\end{tabular}

Sumber: Tata usaha SMP Negeri 2 Palopo, tahun ajaran 2018/2019

Statistika Inferensial digunakan untuk menguji hipotesis penelitian, yaitu dengan teknik uji-t, karena uji hipotesis yang digunakan dipersyaratkan memiliki data yang berdistribusi normal dari variansi yang homogen. Sebelum dilakukan pengujian hipotesis, terlebih dahulu dilakukan uji normalitas dan uji homogenitas variansi dari data hasil belajar bahasa Indonesia siswa.

Uji normalitas digunakan untuk mengetahui apakah data yang diteliti berasal dari populasi berdistribusi normal atau tidak. Adapun pedoman untuk mengambil keputusan dalam uji normalitas yaitu:

1) Jika taraf signifikasi $>0,05(p>0,05)$, maka Ho diterima, artinya data berasal dari populasi yang berdistribusi normal.

2) Jika taraf signifikasi $<0,05(\mathrm{p}<0,05)$, maka Ho ditolak. Artinya data tidak berasal dari populasi yang berdistribusi normal.

Uji homogenitas variansi dimaksudkan untuk mengetahui apakah data yang diteliti mempunyai data variansi yang homogeny. Kriteria yang digunakan yaitu:

1) Jika taraf signifikasi $>0,05(\mathrm{p}>0,05)$ maka $\mathrm{H}_{0}$ diterima. Artinya variansi setiap sampel sama (homogen)

2) Jika taraf signifikasi $<0,05(p<0,05)$ maka $H_{0}$ ditolak. Artinya, variansi setiap sampel tidak sama (tidak homogen).

Penguji hipotesis dilakukan dengan melakukan Uji-t. Hasil analisis tersebut kemudian diajukan untuk menguji hipotesis. Dalam pengujian stasistik, hipotesis ini dinyatakan sebagai berikut:

Dengan kriteria pengujian:

$$
\mathrm{H}_{\mathrm{o}}: t h \leq t t \quad \text { lawan } \quad \mathrm{H}_{1}: t h>t t
$$

$\mathrm{H}_{\mathrm{o}}$ : Diterima jika nilai thitung $\leq \mathrm{t}$ table atau $\mathrm{p}>0,05$

$\mathrm{H}_{1}$ : Diterima jika nilai thitung $>\mathrm{t}$ table atau $\mathrm{p}<0,05$

Dengan taraf kesalahan adalah $5 \%$ atau 0,05 . Adapun yang menjadi hipotesis dalam penelitian ini adalah sebagai berikut: 
$\mathrm{H}_{\mathrm{o}}$ : Tekni tidak dapat diterapkan dalam pembelajaran menulis puisi bebas pada siswa kelas VIII SMP Negeri 2 Palopo.

$\mathrm{H}_{1}$ : Teknik dapat diterapkan dalam pembelajaran menulis puisi bebas siswa kelas VIII SMP Negeri 2 Palopo.

\section{Hasil Penelitian dan Pembahasan}

\section{Hasil Analisis Statistika Deskriptif}

Hasil analisis statistika deskriptif menunjukkan tentang karakteristik distribusi skor masing-masing variabel dan sekaligus merupakan jawaban atas masalah deskriptif yang dirumuskan dalam penelitian ini.

\section{a. Hasil Belajar Kelas Kontrol}

Hasil analisis statistika deskriptif berkaitan dengan skor variabel hasil belajar menulis puisi bebas sebelum (pretest) dan setelah (posttest) pembelajaran dengan teknik imagine (khayalan visual) pada kelas kontrol. Kelas kontrol merupakan kelas yang pembelajarannya tanpa menggunakan teknik imagine (khayalan visual).

1) Hasil pembelajaran pretest menulis puisi bebas siswa kelas VIII D SMP Negeri

2 Palopo

Berikut ini adalah tabel yang berisi tentang gambaran skor hasil pembelajaran menulis puisi bebas siswa data pretest yang ditampilkan pada tabel dan selengkapnya dapat dilihat pada lampiran.

Tabel 6. Statistika deskriptif skor pretest hasil pembelajaran menulis puisi bebas siswa kelas VIII D SMP Negeri 2 Palopo pada Kelas Kontrol

\begin{tabular}{lc}
\multicolumn{1}{c}{ Statistik } & Nilai Statistik \\
\hline Ukuran Sampel & 24 \\
Rata-rata & 61,46 \\
Standar Deviasi & 13,87 \\
Variansi & 192,35 \\
Rentang Skor & 50 \\
Nilai Terendah & 35 \\
Nilai tertinggi & 85 \\
\hline
\end{tabular}

Sumber: Hasil Analisis Data Primer (2019)

Berdasarkan tabel 6 menunjukkan bahwa skor rata-rata kemampuan awal (pretest) menulis puisi bebas siswa kelas VIII D SMP Negeri 2 Palopo memperoleh skor rata-rata 61,46 dari skor ideal 100 dengan standar deviasi 13,87, skor tertinggi 85 dan skor terendah 35.

Berikut ini adalah distribusi frekuensi dan persentase perolehan skor pretest menulis puisi dari 24 siswa diperoleh gambaran bahwa tidak ada siswa yamg mampu memperoleh nilai 100 sebagai nilai maksimal.

Tabel 7. Distribusi frekuensi dan persentase skor pretest hasil menulis puisi bebas siswa Kelas Kontrol 


\begin{tabular}{cccc}
\hline No. & Nilai Siswa & Frekuensi & Persentase (\%) \\
\hline 1. & 35 & 1 & 4,2 \\
2. & 40 & 2 & 8,3 \\
3. & 45 & 2 & 8,3 \\
4. & 50 & 1 & 4,2 \\
5. & 55 & 2 & 8,3 \\
6. & 60 & 5 & 20,9 \\
7. & 65 & 2 & 8,3 \\
8. & 70 & 3 & 12,5 \\
9. & 75 & 3 & 12,5 \\
10. & 80 & 2 & 8,3 \\
11. & 85 & 1 & 4,2 \\
\hline \multicolumn{2}{c}{ Jumlah } \\
\hline
\end{tabular}

Sumber: Hasil Analisis Data Primer (2019)

Berdasarkan tabel 7 menunjukkan bahwa tes awal dari 24 Siswa kelas VIII D SMP Negeri 7 Palopo nilai tertinggi 85 diperoleh 1 siswa $(4,2 \%)$, nilai 80 diperoleh 2 siswa (8,3\%), nilai 75 diperoleh 3 siswa (12,5\%), nilai 70 diperoleh 3 siswa (12,5\%), nilai 65 diperoleh 2 siswa (8,3\%), nilai 60 diperoleh 5 siswa (20,8\%), nilai 55 diperoleh 2 siswa (8,3\%), nilai 50 diperoleh 1 siswa $(4,3 \%)$, nilai 45 diperoleh 2 siswa (8,3\%), nilai 40 diperoleh 2 siswa (8,3\%), dan nilai 35 diperoleh 1 siswa $(4,2 \%)$.

Tabel 8. Kategori Kemampuan Menulis Puisi Bebas Hasil Pretest Siswa Kelas VIII D SMP Negeri 2 Palopo Kelas Kontrol

\begin{tabular}{|c|c|c|c|c|}
\hline No & Skor & Kategori & Frekuensi & Persentase (\%) \\
\hline 1. & $0-54$ & Sangat rendah & 6 & 25 \\
\hline 2. & $55-64$ & Rendah & 7 & 29,2 \\
\hline 3. & $65-79$ & Sedang & 8 & 33,3 \\
\hline 4. & $80-89$ & Tinggi & 3 & 12,5 \\
\hline 5. & $90-100$ & Sangat tinggi & 0 & 0 \\
\hline \multicolumn{3}{|c|}{ Jumlah } & 24 & 100 \\
\hline
\end{tabular}

Apabila diilustrasikan ke dalam bentuk grafik, maka bentuknya akan tampak seperti gambar berikut:

\section{Gambar 1. Distribusi dan Frekuensi Hasil Pretest Menulis Puisi Bebas Kelas Kontrol}

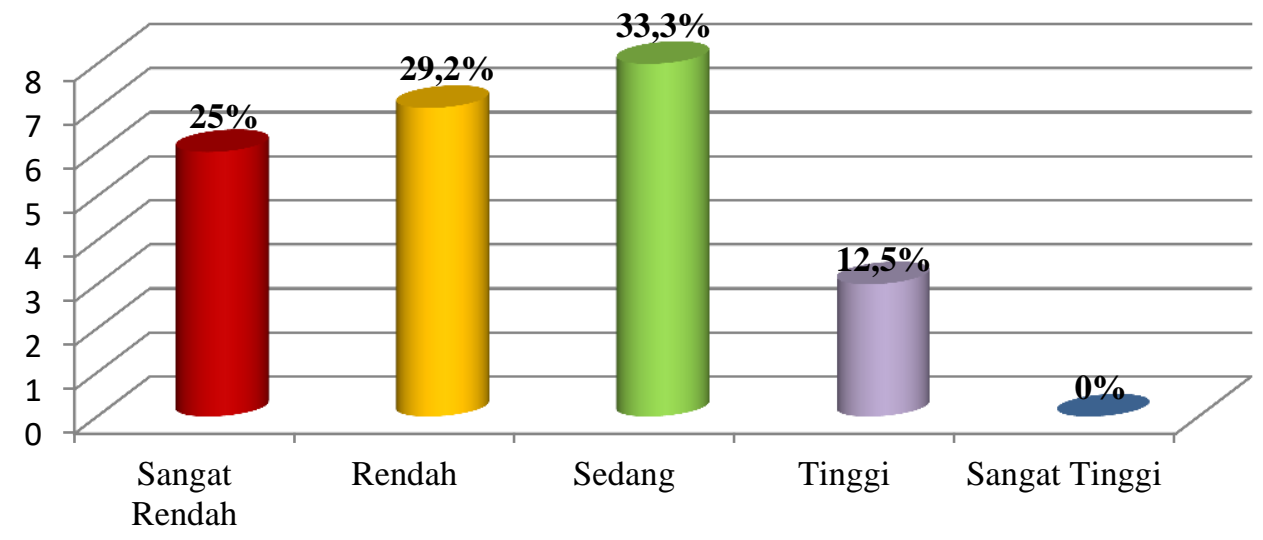


Berdasarkan tabel dan grafik tersebut, tampak bahwa dari 24 Siswa Kelas VIII D SMP Negeri 2 Palopo terdapat 6 orang siswa (25\%) yang hasil belajarnya masuk dalam kategori sangat rendah, 7 orang siswa $(29,2 \%)$ masuk dalam kategori rendah, 8 orang siswa (33,3\%) masuk dalam kategori sedang, 3 orang siswa $(12,5 \%)$ masuk dalam kategori tinggi, dan tidak ada siswa yang masuk dalam kategori sangat tinggi (0\%).

Berdasarkan tabel 6, maka diperoleh skor rata-rata hasil belajar pada pretest kelas kontrol yaitu sebesar 61,6. Jika skor rata-rata siswa tersebut dikonsultasikan dengan tabel 8, maka kemampuan hasil belajar siswa dapat dikategorikan sedang.

Hasil analisis pada tabel di atas data dimasukkan ke dalam kriteria ketuntasan yang telah ditetapkan oleh sekolah yang bersangkutan sesuai dengan KKM mata pelajaran bahasa Indonesia.

Tabel 9. Hasil pencapaian KKM pretest menulis puisi bebas siswa kelas VIII D SMP Negeri 2 Palopo Kelas Kontrol

\begin{tabular}{llcc}
\hline No & Perolehan Nilai & Frekuensi & Persentasi (\%) \\
\hline 1 & Nilai $75 \geq$ ke atas & 6 & 25 \\
2 & Nilai $75<$ ke bawah & 18 & 75 \\
\hline \multicolumn{2}{c}{ Jumlah } & & 100
\end{tabular}

Sumber: Data Primer (2019)

Apabila diilustrasikan ke dalam bentuk grafik, maka bentuknya akan tampak pada gambar berikut:

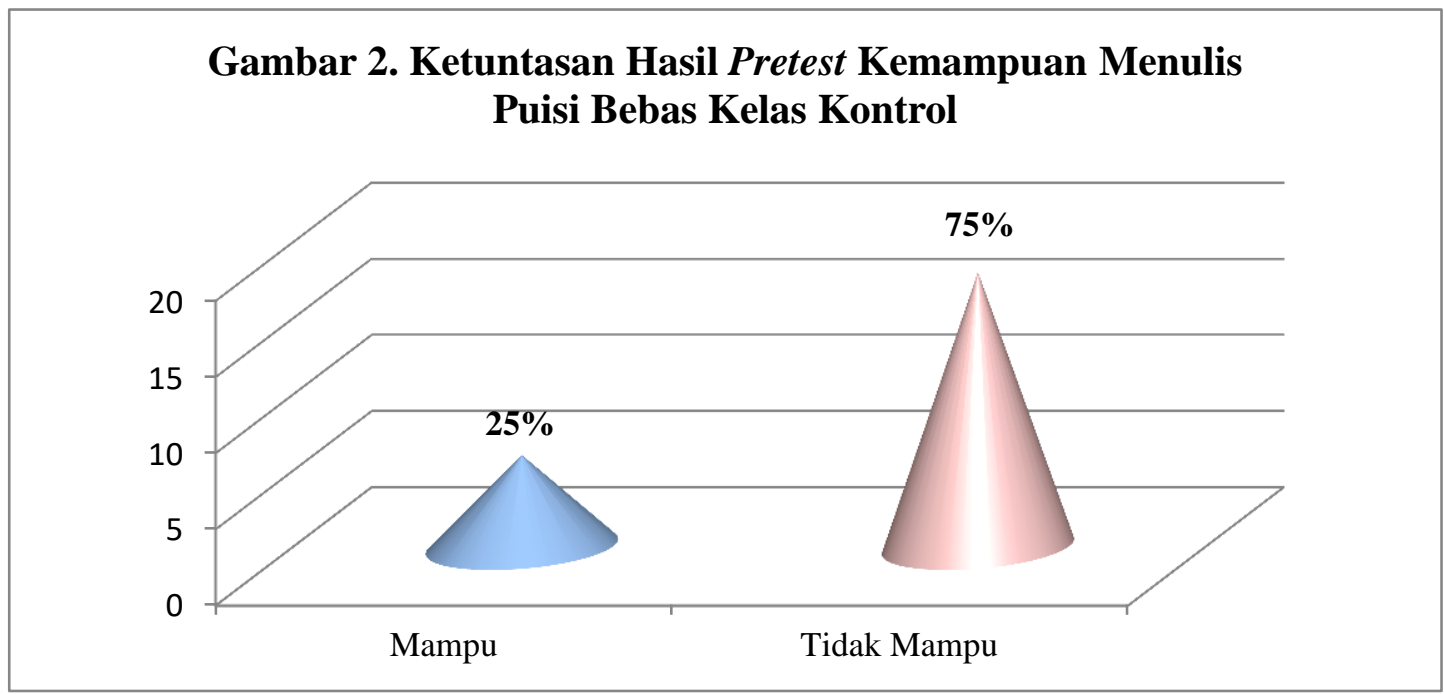

Berdasarkan pada tabel gambar di atas, dapat diketahui bahwa hasil pencapain KKM pretest kelas kontrol dalam menulis puisi bebas, memiliki tolak ukur kemampuan siswa yakni 25\% siswa memperolah nilai 75 ke atas, dan $75 \%$ jumlah siswa memperoleh nilai dibawah 75 . Jadi, dapat disimpulkan bahwa 
kategori kecenderungan kelas kontrol pada saat pretest rata-rata tergolong tidak mampu.

2) Hasil pembelajaran posttest menulis puisi bebas siswa kelas VIII D SMP Negeri 2 Palopo

Berikut ini adalah tabel yang berisi tentang gambaran skor hasil pembelajaran menulis puisi bebas siswa yang diperoleh dari data potstest yang ditampilkan pada tabel dan selengkapnya dapat dilihat pada lampiran.

Tabel 10. Statistika deskriptif hasil pembelajaran posttest menulis puisi bebas siswa kelas VIII D SMP Negeri 2 Palopo Kelas Kontrol

\begin{tabular}{lc}
\multicolumn{1}{c}{ Statistik } & Nilai Statistik \\
\hline Ukuran Sampel & 24 \\
Rata-rata & 62,71 \\
Standar Deviasi & 11,89 \\
Variansi & 141,26 \\
Rentang Skor & 45 \\
Nilai Terendah & 40 \\
Nilai tertinggi & 85 \\
\hline
\end{tabular}

Sumber: Hasil Analisis Data Primer (2009)

Berdasarkan tabel di atas menunjukkan bahwa skor rata-rata kemampuan akhir (posttest) menulis puisi bebas siswa kelas VIII D SMP Negeri 2 Palopo memperoleh skor rata-rata 62,71 dari skor ideal 100 dengan standar deviasi 11,89, skor tertinggi 85 dan skor terendah 45.

Berikut ini adalah distribusi frekuensi dan persentase perolehan skor posttest menulis puisi diperoleh gambaran bahwa tidak ada siswa yang mampu memperoleh nilai 100 sebagai nilai maksimal.

Tabel 11. Distribusi frekuensi dan persentase skor posttest hasil menulis puisi bebas siswa kelas VIII D SMP Negeri 2 Palopo Kelas Kontrol

\begin{tabular}{cccc}
\hline No. & Nilai Siswa & Frekuensi & Persentase (\%) \\
\hline 1. & 40 & 1 & 4,2 \\
2. & 45 & 2 & 8,3 \\
3. & 50 & 2 & 8,3 \\
4. & 55 & 3 & 12,5 \\
5. & 60 & 4 & 16,7 \\
6. & 65 & 2 & 8,3 \\
7. & 70 & 6 & 25,0 \\
8. & 75 & 1 & 4,2 \\
9. & 80 & 2 & 8,3 \\
10. & 85 & 1 & 4,2 \\
\hline \multicolumn{2}{c}{ Jumlah } \\
\hline
\end{tabular}

Sumber: Hasil Analisis Data Primer (2019)

Berdasarkan tabel di atas menunjukkan bahwa dari 24 siswa kelas VIII D SMP Negeri 7 nilai 85 diperoleh 1 siswa (4,2\%), nilai 80 diperoleh 2 siswa 
(8,3\%), nilai 75 diperoleh 1 siswa (4,2\%), nilai 70 diperoleh 6 siswa (25,0\%), nilai 65 diperoleh 2 siswa $(4,2 \%)$, nilai 60 diperoleh 4 siswa $(16,7 \%)$, nilai 55 diperoleh 3 siswa (12,5\%), nilai 50 diperoleh 2 siswa (8,3\%), nilai 45 diperoleh 2 siswa (8,3\%), dan nilai 40 diperoleh 1 siswa $(4,2 \%)$.

Tabel 12. Kategori Kemampuan Menulis Puisi Bebas Hasil Posttest Siswa Kelas VIII D SMP Negeri 2 Palopo Kelas Kontrol

\begin{tabular}{|c|c|c|c|c|}
\hline No & Skor & Kategori & Frekuensi & Persentase (\%) \\
\hline 1. & $0-54$ & Sangat rendah & 5 & 20,8 \\
\hline 2. & $55-64$ & Rendah & 7 & 29,2 \\
\hline 3. & $65-79$ & Sedang & 9 & 37,5 \\
\hline 4. & $80-89$ & Tinggi & 3 & 12,5 \\
\hline 5. & $90-100$ & Sangat tinggi & 0 & 0 \\
\hline \multicolumn{3}{|c|}{ Jumlah } & 24 & 100 \\
\hline
\end{tabular}

Apabila diilustrasikan ke dalam bentuk grafik, maka bentuknya akan tampak seperti gambar berikut:

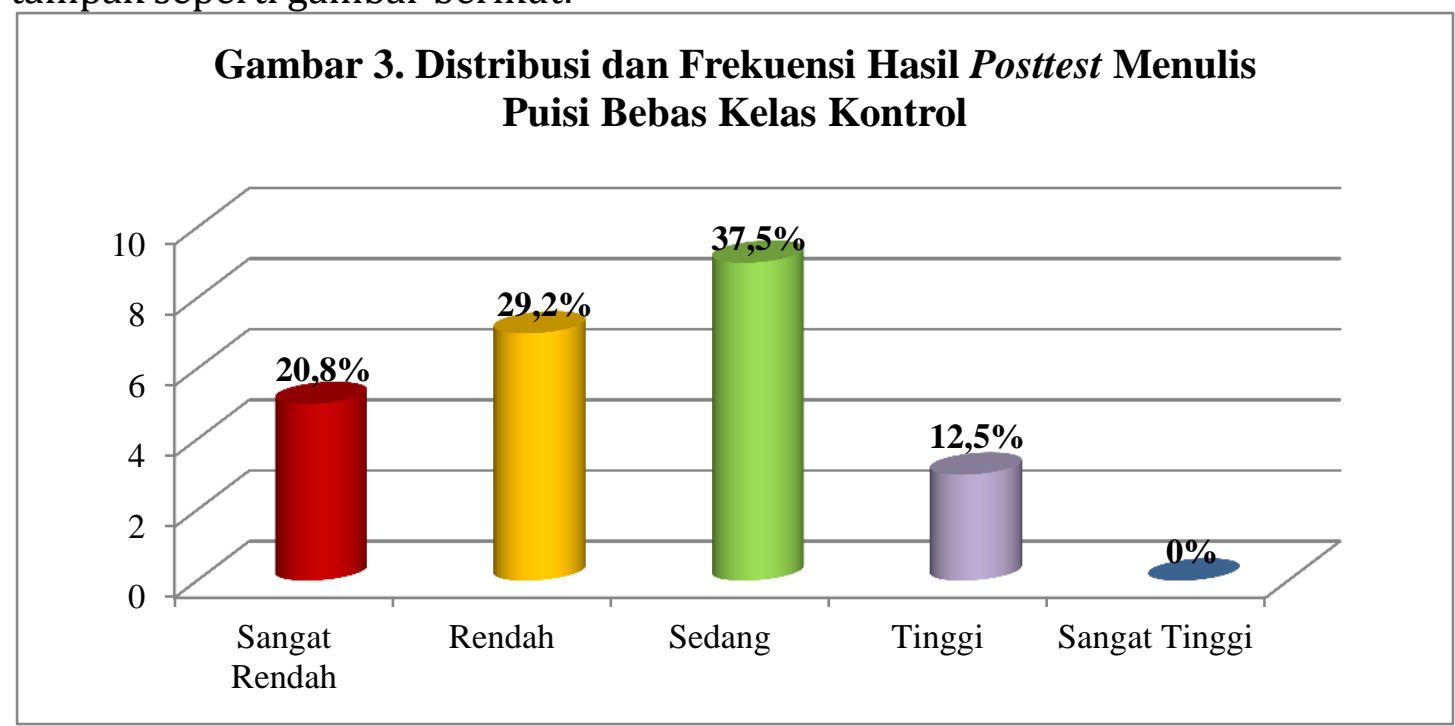

Berdasarkan tabel dan grafik tersebut, tampak bahwa dari 24 Siswa Kelas VIII D SMP Negeri 2 Palopo terdapat 5 orang siswa $(20,8 \%)$ yang hasil belajarnya masuk dalam kategori sangat rendah, 7 orang siswa $(29,2 \%)$ masuk dalam kategori rendah, 9 orang siswa $(37,5 \%)$ masuk dalam kategori sedang, 3 orang siswa $(12,5 \%)$ masuk dalam kategori tinggi, dan tidak ada siswa yang masuk dalam kategori sangat tinggi $(0 \%)$.

Berdasarkan tabel 10, maka diperoleh skor rata-rata hasil belajar pada posttest kelas kontrol yaitu sebesar 62,71. Jika skor rata-rata siswa tersebut dikonsultasikan dengan tabel 12, maka kemampuan hasil belajar siswa dapat dikategorikan sedang.

Hasil analisis pada tabel di atas, data dimasukkan ke dalam kriteria ketuntasan yang telah ditetapkan oleh sekolah yang bersangkutan sesuai dengan 
KKM mata pelajaran bahasa Indonesia.

Tabel 13. Hasil pencapaian KKM posttest menulis puisi bebas siswa kelas VIII D SMP Negeri 2 Palopo Kelas Kontrol

\begin{tabular}{llcc}
\hline No & Perolehan Nilai & Frekuensi & Persentasi (\%) \\
\hline 1 & Nilai $75 \geq$ ke atas & 4 & 16,67 \\
2 & Nilai $75<$ ke bawah & 20 & 83,33 \\
\hline & & Jumlah & 100 \\
\hline
\end{tabular}

Sumber: Data Primer (2019)

Apabila diilustrasikan ke dalam bentuk grafik, maka bentuknya akan tampak pada gambar berikut:

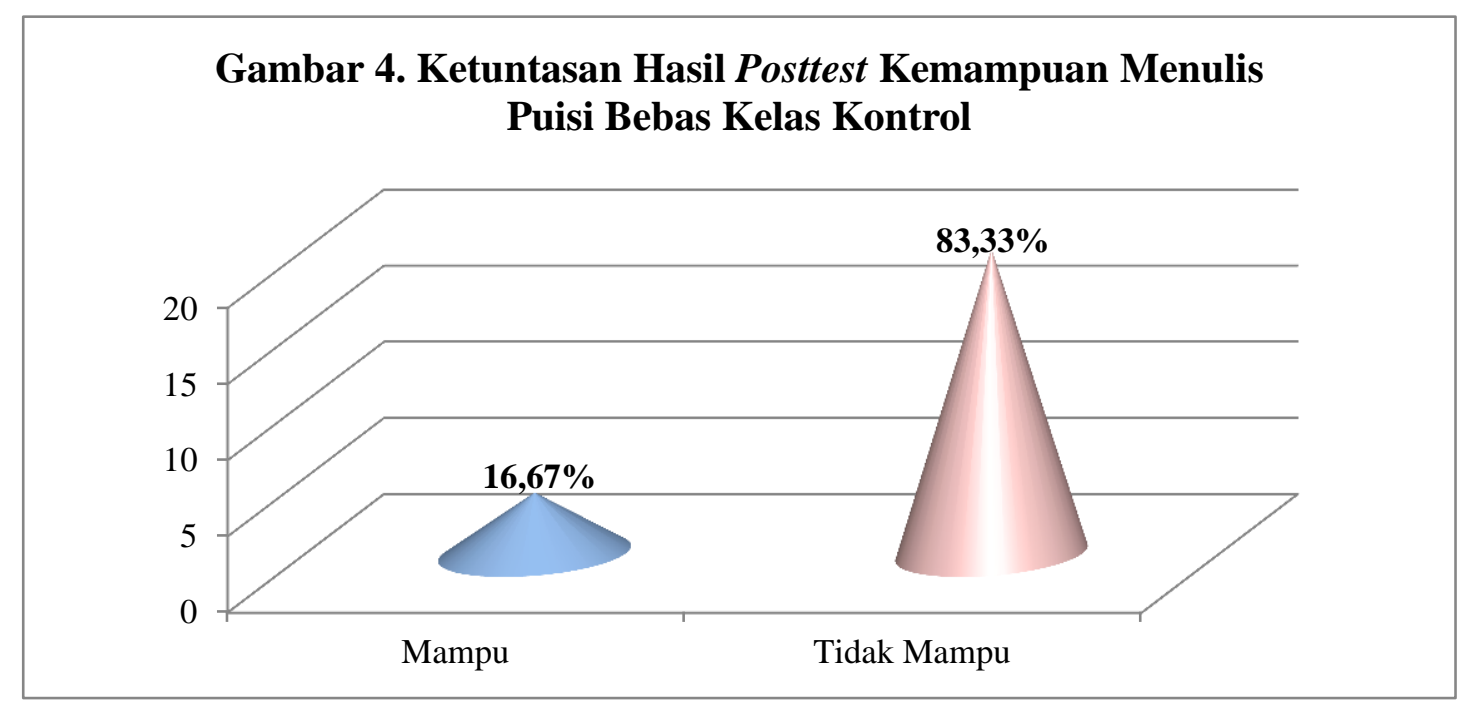

Berdasarkan pada tabel dan gambar di atas dapat diketahui bahwa hasil pencapain KKM posttest kelas kontrol dalam menulis puisi untuk kategori mampu diperoleh 4 siswa $(16,67)$ nilai 75 ke atas, dan kategori tidak mampu diperoleh 20 siswa (83,33\%) nilai dibawah 75. Dengan demikian, dapat diartikan bahwa tingkat kemampuan siswa dalam pembelajaran menulis puisi bebas pada saat posttest dinyatakan dalam kategori tidak mampu.

\section{b. Hasil Belajar Kelas Eksperimen}

Hasil analisis statistika deskriptif berkaitan dengan skor variabel hasil belajar menulis puisi bebas sebelum (pretest) dan setelah (posttest) pembelajaran dengan teknik imagine (khayalan visual) pada kelas eksperimen.

1) Hasil pembelajaran menulis puisi bebas siswa kelas VIII A SMP Negeri 2

Palopo sebelum (pretest) penerapan teknik imagine (khayalan visual)

Jumlah siswa pada kelas eksperimen sebanyak 31 orang tetapi pada waktu pelaksanaan pengumpulan data hanya diikuti oleh 24 siswa. Hal itu terjadi karena ada beberapa siswa yang terlibat dalam kegiatan sekolah.

Berikut ini adalah tabel yang berisi tentang gambaran skor hasil pembelajaran menulis puisi bebas siswa sebelum diterapkan teknik imagine (khayalan visual) yang diperoleh dari data pretest yang ditampilkan pada tabel 
dan selengkapnya dapat dilihat pada lampiran.

Tabel 14. Statistika deskriptif hasil pembelajaran menulis puisi bebas siswa sebelum (pretest) penerapan teknik imagine (khayalan visual) Kelas Eksperimen

\begin{tabular}{lc}
\multicolumn{1}{c}{ Statistik } & Nilai Statistik \\
\hline Ukuran Sampel & 24 \\
Rata-rata & 62,29 \\
Standar Deviasi & 15,25 \\
Variansi & 232,56 \\
Rentang Skor & 55 \\
Nilai Terendah & 35 \\
Nilai tertinggi & 90 \\
\hline
\end{tabular}

Sumber: Hasil Analisis Data Primer (2019)

Berdasarkan tabel di atas menunjukkan bahwa skor rata-rata kemampuan awal (pretest) menulis puisi bebas siswa kelas VIII A SMP Negeri 2 Palopo memperoleh skor rata-rata 62,29 dari skor ideal 100 dengan standar deviasi 15,25 , skor tertinggi 90 dan skor terendah 35.

Berikut ini adalah distribusi frekuensi dan persentase perolehan skor pretest menulis puisi sebelum diberikan perlakuan dalam hal ini penerapan teknik imagine.

Tabel 15. Distribusi frekuensi dan persentase skor hasil menulis puisi bebas siswa sebelum (pretest) penerapan teknik imagine (khayalan visual) Kelas Eksperimen

\begin{tabular}{cccc}
\hline No. & Nilai Siswa & Frekuensi & Persentase (\%) \\
\hline 1. & 35 & 1 & 4,2 \\
2. & 40 & 2 & 8,3 \\
3. & 45 & 2 & 8,3 \\
4. & 50 & 2 & 8,3 \\
5. & 55 & 2 & 8,3 \\
6. & 60 & 2 & 8,3 \\
7. & 65 & 3 & 12,5 \\
8. & 70 & 5 & 20,9 \\
9. & 75 & 1 & 4,2 \\
10. & 80 & 2 & 4,2 \\
11. & 85 & 1 & 8,3 \\
12. & 90 & & 4,2 \\
\hline \multicolumn{4}{r}{ Jumlah } \\
\hline
\end{tabular}

Sumber: Hasil Analisis Data Primer (2019)

Berdasarkan tabel di atas menunjukkan bahwa dari 24 Siswa kelas VIII A SMP Negeri 2 Palopo sebelum penerapan teknik imagine (khayalan visual) nilai tertinggi 90 diperoleh 1 siswa (4,2\%), nilai 85 diperoleh 2 siswa (8,3\%), nilai 80 
diperoleh 1 siswa (4,2\%), nilai 75 diperoleh 1 siswa (4,2\%), nilai 70 diperoleh 5 siswa (20,8\%), nilai 65 diperoleh 3 siswa (12,5\%), nilai 60 diperoleh 2 siswa $(8,3 \%)$, nilai 55 diperoleh 2 siswa (8,3\%), nilai 50 diperoleh 2 siswa (8,3\%), nilai 45 diperoleh 2 siswa (8,3\%), nilai 40 diperoleh 2 siswa (8,3\%), dan nilai 35 diperoleh 1 siswa $(4,2 \%)$.

Tabel 16. Kategori Kemampuan Menulis Puisi Bebas Sebelum (Pretest) Penerapan Teknik Imagine (Khayalan Visual) Siswa Kelas VIII A SMP Negeri 2 Palopo Kelas Eksperimen

\begin{tabular}{|c|c|c|c|c|}
\hline No & Skor & Kategori & Frekuensi & Persentase (\%) \\
\hline 1. & $0-54$ & Sangat rendah & 7 & 29,1 \\
\hline 2. & $55-64$ & Rendah & 4 & 16,6 \\
\hline 3. & $65-79$ & Sedang & 9 & 37,6 \\
\hline 4. & $80-89$ & Tinggi & 3 & 12,5 \\
\hline 5. & $90-100$ & Sangat tinggi & 1 & 4,2 \\
\hline \multicolumn{3}{|c|}{ Iumlah } & 24 & 100 \\
\hline
\end{tabular}

Apabila diilustrasikan ke dalam bentuk grafik, maka bentuknya akan tampak seperti gambar berikut:

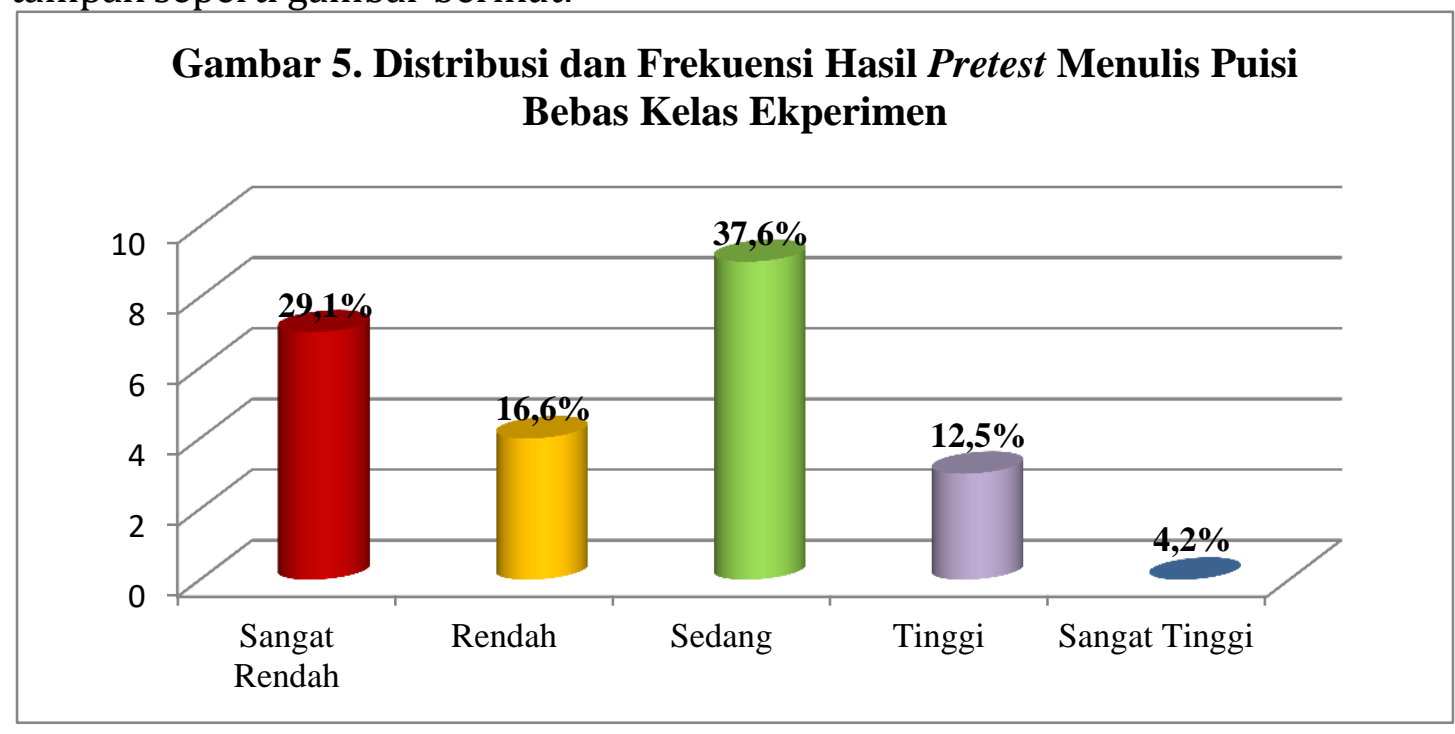

Berdasarkan tabel dan grafik tersebut, tampak bahwa dari 24 Siswa Kelas VIII A SMP Negeri 2 Palopo terdapat 7 orang siswa $(29,1 \%)$ yang hasil belajarnya masuk dalam kategori sangat rendah, 4 orang siswa $(16,6 \%)$ masuk dalam kategori rendah, 9 orang siswa $(37,6 \%)$ masuk dalam kategori sedang, 3 orang siswa $(12,5 \%)$ masuk dalam kategori tinggi, dan 1 orang siswa $(4,2 \%)$ masuk dalam kategori sangat tinggi.

Berdasarkan tabel 14, maka diperoleh skor rata-rata hasil belajar pada pretest kelas eksperimen yaitu sebesar 62,29. Jika skor rata-rata siswa tersebut dikonsultasikan dengan tabel 16, maka kemampuan hasil belajar siswa dapat dikategorikan sedang. 
Hasil analisis pada tabel di atas data dimasukkan ke dalam kriteria ketuntasan yang telah ditetapkan oleh sekolah yang bersangkutan sesuai dengan KKM mata pelajaran bahasa Indonesia.

Tabel 17. Hasil pencapaian KKM pretest menulis puisi bebas sebelum penerapan teknik Imagine siswa kelas VIII A SMP Negeri 2 Palopo Kelas Eksperimen

\begin{tabular}{llcc}
\hline No & Perolehan Nilai & Frekuensi & Persentasi (\%) \\
\hline 1 & Nilai $75 \geq$ ke atas & 5 & 20,83 \\
2 & Nilai $75<$ ke bawah & 19 & 79,17 \\
\hline & & Jumlah & 100 \\
\hline
\end{tabular}

Sumber: Data Primer (2019)

Apabila diilustrasikan ke dalam bentuk grafik, maka bentuknya akan tampak pada gambar berikut:

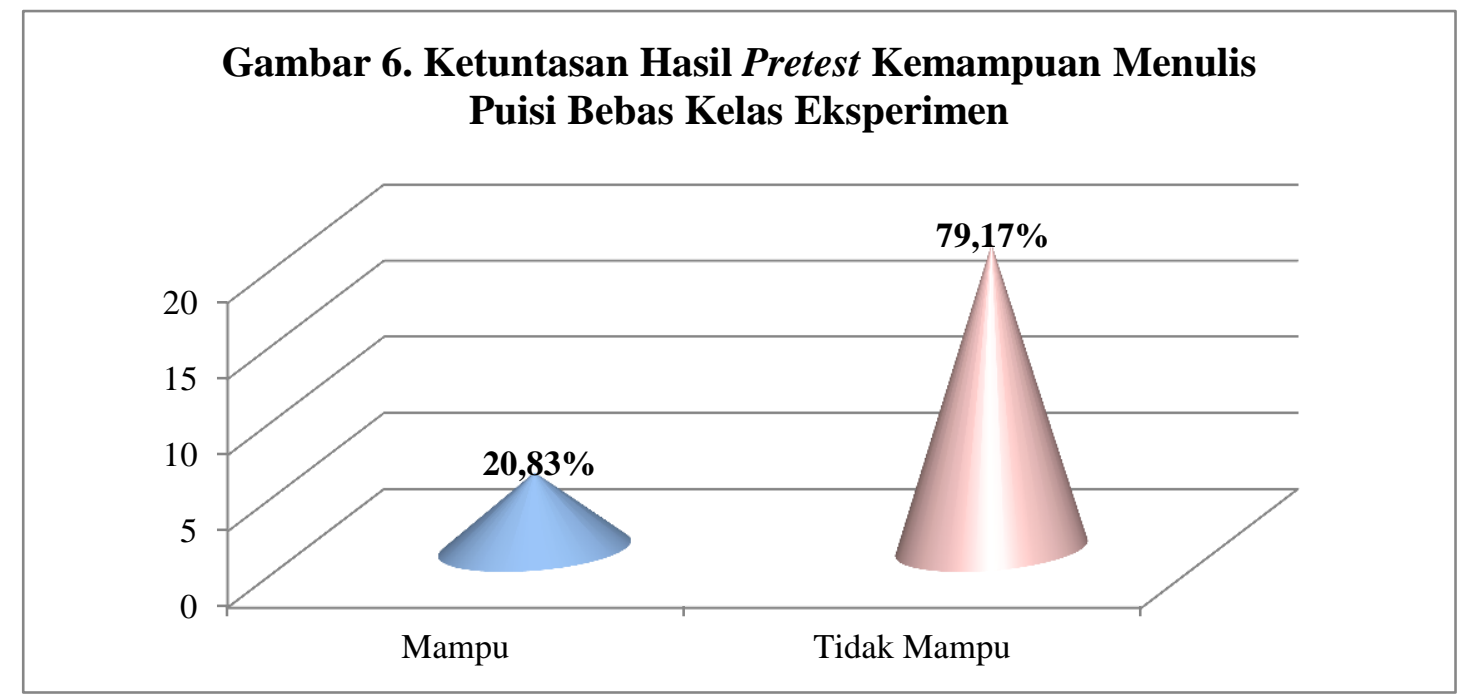

Berdasarkan pada di atas dapat diketahui bahwa hasil pencapain KKM pretest kelas eksperimen dalam menulis puisi bebas, memiliki tolak ukur kemampuan siswa yakni 20,83\% siswa memperolah nilai 75 ke atas, dan 79,17 jumlah siswa memperoleh nilai dibawah 75 . Jadi dapat disimpulkan bahwa kategori kecebderungan kelas eksperimen pada saat pretest rata-rata tergolong tidak mampu.

2) Hasil pembelajaran menulis puisi bebas siswa kelas VIII A SMP Negeri 2 Palopo setelah (posttest) penerapan teknik imagine (khayalan visual)

Berikut ini adalah tabel yang berisi tentang gambaran skor hasil pembelajaran menulis puisi bebas siswa sebelum diterapkan teknik imagine (khayalan visual) yang diperoleh dari data potstest yang ditampilkan pada tabel dan selengkapnya dapat dilihat pada lampiran.

Tabel 18. Statistika deskriptif hasil pembelajaran menulis puisi bebas siswa setelah (posttest) penerapan teknik imagine (khayalan visual) Kelas 
Eksperimen

\begin{tabular}{lc}
\multicolumn{1}{c}{ Statistik } & Nilai Statistik \\
\hline Ukuran Sampel & 24 \\
Rata-rata & 73,96 \\
Standar Deviasi & 11,70 \\
Variansi & 136,91 \\
Rentang Skor & 40 \\
Nilai Terendah & 50 \\
Nilai tertinggi & 90 \\
\hline
\end{tabular}

Sumber: Hasil Analisis Data Primer (2009)

Berdasarkan tabel 15 menunjukkan bahwa skor rata-rata kemampuan akhir (posttest) menulis puisi bebas siswa kelas VIII A SMP Negeri 2 Palopo memperoleh skor rata-rata 73,96 dari skor ideal 100 dengan standar deviasi 11,70, skor tertinggi 90 dan skor terendah 50.

Berikut ini adalah distribusi frekuensi dan persentase perolehan skor posttest menulis puisi setelah diberikan perlakuan dalam hal ini penerapan teknik imagine.

Tabel 19. Distribusi frekuensi dan persentase skor hasil menulis puisi bebas siswa setelah (posttest) penerapan teknik imagine (khayalan visual) kelas eksperimen

\begin{tabular}{cccc}
\hline No. & Nilai Siswa & Frekuensi & Persentase (\%) \\
\hline 1. & 50 & 1 & 4,2 \\
2. & 55 & 1 & 4,2 \\
3. & 60 & 3 & 12,5 \\
4. & 65 & 1 & 4,2 \\
5. & 70 & 5 & 20,8 \\
6. & 75 & 4 & 16,7 \\
7. & 80 & 2 & 8,3 \\
8. & 85 & 3 & 12,5 \\
9. & 90 & 4 & 16,7 \\
\hline \multicolumn{2}{c}{ Jumlah } & & 100 \\
\hline
\end{tabular}

Sumber: Hasil Analisis Data Primer (2019)

Berdasarkan tabel di atas menunjukkan bahwa dari 24 Siswa kelas VIII A SMP Negeri 2 Palopo setelah penerapan teknik imagine (khayalan visual) nilai tertinggi 90 diperoleh 4 siswa (16,7\%), nilai 85 diperoleh 3 siswa (12,5\%), nilai 80 diperoleh 2 siswa (8,3\%), nilai 75 diperoleh 4 siswa (16,7\%), nilai 70 diperoleh 5 siswa $(20,8 \%)$, nilai 65 diperoleh 1 siswa $(4,2 \%)$, nilai 60 diperoleh 3 siswa (12,5\%), nilai 55 diperoleh 1 siswa (4,2\%), dan nilai 50 diperoleh 1 siswa $(4,2 \%)$.

Tabel 20. Kategori Kemampuan Menulis Puisi Bebas Hasil Setelah (Posttest) Penerapan Teknik Imagine Siswa Kelas VIII A SMP Negeri 2 Palopo 
Kelas Eksperimen

\begin{tabular}{ccccc}
\hline No & Skor & Kategori & Frekuensi & Persentase (\%) \\
\hline 1. & $0-54$ & Sangat rendah & 1 & 4,2 \\
2. & $55-64$ & Rendah & 4 & 16,7 \\
3. & $65-79$ & Sedang & 10 & 41,6 \\
4. & $80-89$ & Tinggi & 5 & 20,8 \\
5. & $90-100$ & Sangat tinggi & 4 & 16,7 \\
\hline \multicolumn{6}{c}{ Jumlah } & 24 & 100 \\
\hline
\end{tabular}

Apabila diilustrasikan ke dalam bentuk grafik, maka bentuknya akan tampak seperti gambar berikut:

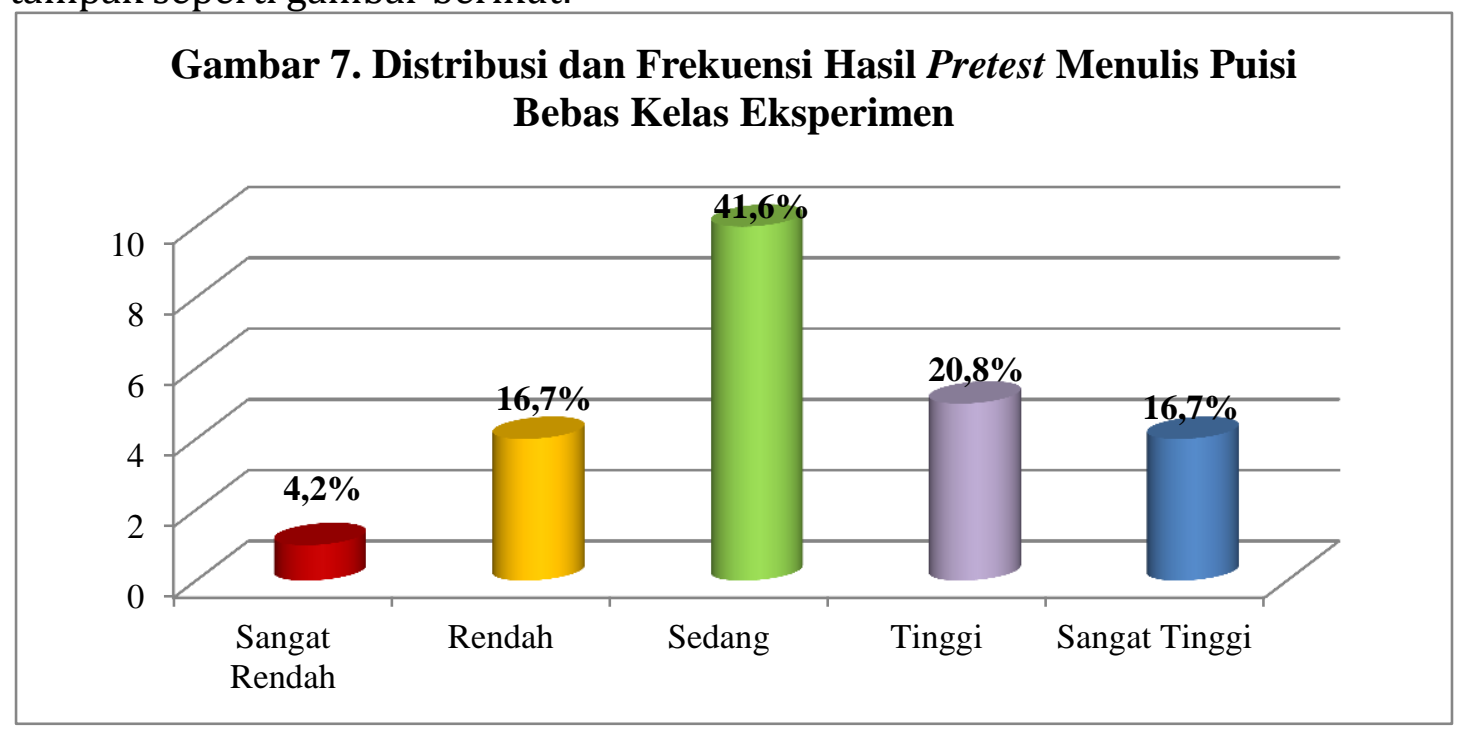

Berdasarkan tabel dan grafik tersebut, tampak bahwa dari 24 Siswa Kelas VIII A SMP Negeri 2 Palopo terdapat 1 orang siswa (4,2\%) yang hasil belajarnya masuk dalam kategori sangat rendah, 4 orang siswa $(16,7 \%)$ masuk dalam kategori rendah, 10 orang siswa $(41,6 \%)$ masuk dalam kategori sedang, 5 orang siswa $(20,8 \%)$ masuk dalam kategori tinggi, dan 4 orang siswa $(16,7 \%)$ masuk dalam kategori sangat tinggi.

Berdasarkan tabel 18, maka diperoleh skor rata-rata hasil belajar pada posttest kelas kontrol yaitu sebesar 73,96. Jika skor rata-rata siswa tersebut dikonsultasikan dengan tabel 20, maka kemampuan hasil belajar siswa dapat dikategorikan sedang.

Hasil analisis pada tabel di atas, data dimasukkan ke dalam kriteria ketuntasan yang telah ditetapkan oleh sekolah yang bersangkutan sesuai dengan KKM mata pelajaran bahasa Indonesia.

Tabel 21. Hasil pencapaian KKM menulis puisi bebas setelah (posttest) penerapan teknik imagine siswa kelas VIII A SMP Negeri 2 Palopo kelas eksperimen 


\begin{tabular}{llcc}
\hline No & Perolehan Nilai & Frekuensi & Persentasi $(\%)$ \\
\hline 1 & Nilai $75 \geq$ ke atas & 13 & 54,17 \\
2 & Nilai $75<$ ke bawah & 11 & 45,83 \\
\hline & & Jumlah & 100 \\
\hline
\end{tabular}

Sumber: Data Primer (2019)

Apabila diilustrasikan ke dalam bentuk grafik, maka bentuknya akan tampak pada gambar berikut:

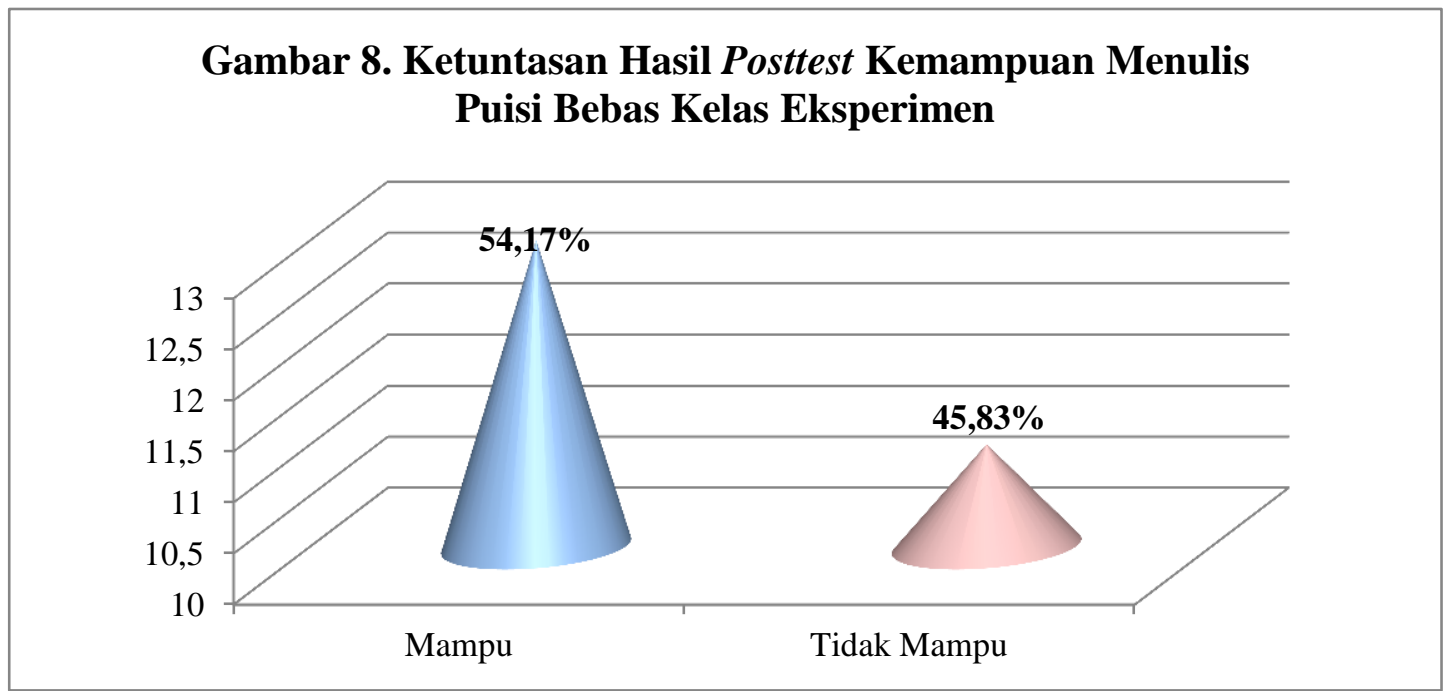

Berdasarkan pada tabel dan grafik di atas, dapat diketahui bahwa hasil pencapain KKM posttest kelas eksperimen dalam menulis puisi bebas berada pada kategori mampu, kategori mampu diperoleh 13 siswa (54,17\%) nilai 75 ke atas, dan kategori tidak mampu diperoleh 11 siswa (45,83\%) nilai dibawah 75. Dengan demikian, dapat diartikan bahwa tingkat kemampuan siswa dalam penerapan teknik imagine (khayalan visual) dinyatakan dalam kategori mampu karena mengalami peningkatan. 


\section{Simpulan}

Berdasarkan hasil penelitian yang telah dilakukan menunjukkan bahwa hasil belajar siswa sebelum penerapan teknik imagine (kelas kontrol) berada pada kategori rendah, dan setelah penerapan teknik imagine (kelas eksperimen) berada pada kategori sedang. Berdasarkan uji $\mathrm{t}$ Independent-Samples $t$ Test, diperoleh nilai $\alpha=0,05$ dan Sig. (2-tailed) =0,002, ini 0,002 $<0,05$, maka $\left(\mathrm{H}_{0}\right)$ ditolak dan $\left(\mathrm{H}_{1}\right)$ diterima, yang artinya terdapat peningkatan pada hasil belajar siswa sesudah menggunakan teknik imagine pada kelas eksperimen dalam pembelajaran menulis puisi bebas. Hal ini berarti proses pembelajaran menulis puisi bebas siswa kelas VIII SMP Negeri 2 Palopo efektif setelah diterapkan teknik imagine. Berdasarkan kategori ketuntasan hasil pencapaian KKM untuk kelas yang menerapkan teknik imagine yakni kelas eksperimen, siswa yang mendapatkan nilai > 75 sebanyak 13 siswa $(54,17 \%)$ dan siswa yang mendapat nilai < 75 sebanyak 11 siswa $(45,84 \%)$ sehingga persentase nilai yang mendapatkan nilai $>75$ lebih besar dibandingkan nilai $<75$, maka dapat disimpulkan bahwa dalam proses pembelajaran puisi bebas teknik imagine efektif digunakan. 
Jurnal Onoma: Pendidikan, Bahasa dan Sastra

PBSI FKIP Universitas Cokroaminoto Palopo

Volume 6 Nomor 1
ISSN 2443-3667 (print)

ISSN 2715-4564 (online)

\section{Daftar Pustaka}

Abrams, 1981. A Glossary Of Literary Terms. New York: Holt-Rinehart and Winston.

Altenbernd, Lewis. 1969. Peningkatan Keterampilan Menulis Puisi Dengan Menggunakan Teknik Koreksi Secara Langsung. Jurnal. Wawancara, Dan Dokumentasi. 1-238. https//unnes.ac.id. Diakses 22 Desember 2018.

Aminuddin. 1985. Pengantar Apresiasi Karya Sastra. Bandung: Sinar Baru.

Dewi, Wahyu Oktarina. 2012. Peningkatan Keterampilan Menulis Puisi Melalui Teknik Imagine dengan Media Poster untuk Siswa Kelas VII SMP Negeri 2 Batangan Pati. Skripsi. Tidak Diterbitkan. Universitas Negeri Surabaya.

Djumingin, Sulastringsih. 2011. Strategi dan Aplikasi Model Pembelajaran Inovatif Bahasa Indonesia. Makassar: Badan Penerbit Universitas Negeri Makassar.

Dalman. 2018. Keterampilan Menulis. Depok: PT Raja Gr afindo Persada.

Hasuna, Aulia. 2017. Penerapan Strategi Imagine Dalam Meningkatka Kemampuan Menulis Puisi Bebas. Jurnal. Bahasa, Sastra, dan Pengajarannya. 151-162. https://stkipbjm.ac.id. Diakses 11 Desember 2018.

http://edisusilo09071991.blogspot.com/2015/01/cara-menulis-puisi-

bebas.html

https://id.wikihow.com/Menuliskan-Puisi-Bebas.

Maman, Suryaman, Wiyatmi. 2012. Puisi Indonesia, Yogyakarta: Ombak.

Nurgiyantoro, Burhan. 2001. Penilaian dalam Pengajaran Bahasa Indonesia. Yogyakarta: BPFE.

Pradopo, Djoko, Rachmat. 2012. Pengkajian Puisi. Yogyakarta: Gadjah Mada University Press.

Preminger, Alex (ed) dkk. 1974. Prenceton Encylofedia of Poetry and Poetics. New Jessery: Princenton University Press.

Sari, Eka Purnama. 2014. Keefektifan Teknik Imagine dalam Pembelajaran Puisi Lirik. Eksperimen Kuasi pada Siswa Kelas VII SMP Negeri 7 Bandung. Skripsi. Tidak Diterbitkan. Universitas Indonesia Bandung.

Sefta, Kurniawan. 2014. Meningkatkan Kemampuan Menulis Puisi Siswa dengan Menerapkan Teknik Imagine (Khayalan Visual) di Kelas XII Bahasa SMAN 4 Kota Bengkulu. Skripsi. Tidak Diterbitkan. Universitas Bengkulu.

Silberman. 2007. Analisis Penerapan Metode Image Streaming (Pengaliran Imaji) Dalam Pembelajaran Menulis Puisi. Jurnal. Bahasa Indonesia. 25-39. https//scholar.google.co.id. Diakses 11 Desember 2018. 
Jurnal Onoma: Pendidikan, Bahasa dan Sastra

ISSN 2443-3667 (print)

PBSI FKIP Universitas Cokroaminoto Palopo

ISSN 2715-4564 (online)

Volume 6 Nomor 1

Sugiyono. 2014. Metode Penelitian Kuantitatif, Kualitatif, dan R\&D. Bandung: Alfabeta.

Sudjiman P. 1992. Memahami Certa Rekaan. Jakarta: PT Dunia Pustaka Jaya.

Tarigan, Henry, Guntur. 2013. Menulis. Bandung: Angkasa.

Zainurrahman. 2013. Menulis: Dari Teori Hingga Praktik. Bandung: Alfabeta. 